\title{
Storage stability of minimally processed pinhão by using edible coatings with antimicrobial characteristics
}

\section{Conservação de pinhão minimamente processado pelo uso de revestimentos comestíveis com características antimicrobianas}

\author{
Michele Krüger Vaz Moreira ${ }^{1 *}$; Rufino Fernando Flores Cantillano²; Eliezer Avila \\ Gandra $^{3}$; Carla Rosane Barboza Mendonça ${ }^{3}$; Caroline Dellinghausen Borges ${ }^{3}$
}

\begin{abstract}
Highlights:
Minimal processing did not increase the respiratory rate of the pinhões.

Pinhões coated with chitosan had higher levels of vitamin C.

The coatings did not cause changes in the aroma and taste of the pinhões.

The chitosan coating improved the storage stability of the pinhões.
\end{abstract}

\begin{abstract}
The pinhão shows high nutritional value; however, its consumption is still low owing to the long cooking time required because it is hard to peel, and it is susceptible to sprouting, larval infestation, and fungal contamination. Thus, this study aimed to evaluate the storage stability of minimally processed pinhão by using edible coatings with antimicrobial characteristics. The pinhões were subjected to minimal processing with the following treatments: Treatment A - control; Treatment B - chitosan; Treatment C xanthan gum and clove essential oil. After drying, they were packed in polyethylene terephthalate and stored at $4{ }^{\circ} \mathrm{C}$ for nine days. The pinhões were analyzed for mass loss, total acidity, reducing sugars, vitamin $\mathrm{C}$, color, firmness, respiratory rate, sensory characteristics, and microbial growth. In general, no differences were observed in mass loss, reducing sugars, and oxygen concentrations of the pinhões after any treatment. In addition, we observed a reduction in acidity and carbon dioxide concentrations, maintenance of color parameters, and the absence of growth of thermotolerant coliforms and coagulasepositive Staphylococcus. Although the minimal processing did not increase the respiratory rate of pinhões, it did not stop the process of seed maturation. Of the coatings evaluated, chitosan coating of the pinhões was associated with a higher content of vitamin $\mathrm{C}$ as well as a lower number of psychrotrophic microorganisms. The coatings did not influence the taste and aroma of the minimally processed pinhões. Key words: Araucaria angustifolia. Chitosan. Clove essential oil. Xanthan.
\end{abstract}

\section{Resumo}

O pinhão apresenta alto valor nutricional, entretanto seu consumo ainda é pouco expressivo devido ao longo tempo de cocção, por apresentar um difícil descasque, ser susceptível ao processo de brotamento, infestação por larvas e deterioração fúngica. Assim, o presente trabalho teve por objetivo avaliar a

\footnotetext{
${ }^{1}$ Discente do Curso de Mestrado do Programa de Pós-Graduação em Nutrição e Alimentos, Universidade Federal de Pelotas, UFPel, Pelotas, RS, Brasil. E-mail: michelekrugernutricao@gmail.com

2 Pesquisador Dr., Empresa Brasileira de Pesquisa Agropecuária, EMBRAPA, Pelotas, RS, Brasil. E-mail: fernando.cantillano@ embrapa.br

3 Profs. Drs., Centro de Ciências Químicas, Farmacêuticas e de Alimentos, UFPel, Pelotas, RS, Brasil. E-mail: gandraea@hotmail. com; carlaufpel@hotmail.com; caroldellin@hotmail.com

* Author for correspondence
} 
conservação de pinhões minimamente processados por meio de revestimentos comestíveis com características antimicrobianas. Os pinhões foram submetidos ao processamento mínimo e após aos diferentes tratamentos: Tratamento A - controle; Tratamento B - quitosana; Tratamento C - xantana e óleo essencial de cravo-da-índia. Após, foram secos sob ventilação forçada, acondicionados em embalagem de Polietileno Tereftalato (PET) e armazenados a $4{ }^{\circ} \mathrm{C}$, durante 9 dias. Foram realizadas avaliações de perda de massa, acidez total titulável, açúcares redutores, vitamina $\mathrm{C}$, firmeza, cor, taxa respiratória, análise sensorial e microbiológica. De uma forma geral, independente do tratamento, pôdese observar comportamento semelhante nas características dos pinhões, em relação ao aumento da perda de massa, dos açúcares redutores, da concentração de oxigênio e da deterioração fisiológica. Além disso, foi observada a redução da acidez e da concentração de dióxido de carbono, bem como a manutenção dos parâmetros de cor e a ausência de crescimento de coliformes termotolerantes e Staphylococcus coagulase positiva. O processamento mínimo não elevou a taxa respiratória dos pinhões, porém não freou o processo de maturação das sementes. Dos revestimentos avaliados, a quitosana possibilitou a obtenção de pinhões com maior teor de vitamina $\mathrm{C}$ e contagem de microrganismos psicrotróficos. Os revestimentos não influenciaram no sabor e aroma dos pinhões minimamente processados.

Palavras-chave: Araucaria angustifolia. Quitosana. Óleo essencial de cravo-da-índia. Xantana.

\section{Introduction}

Pinion is the edible seed of Araucaria angustifolia, which belongs to the Araucariaceae family and is known as Pinhão in the areas where it is cultivated. This plant is native to the Atlantic forest of southern Brazil, and its highest incidence occurs in the state of Paraná, although other states, such as Santa Catarina and Rio Grande do Sul, also produce significant quantities (Companhia Nacional de Abastecimento [CONAB], 2014).

Pinhão has a high energy and nutritional value, is a rich source of carbohydrates and fibers, and contains high amounts of some minerals and vitamins such as iron, phosphorus, magnesium, potassium, and vitamin C (Tabela Brasileira de Composição de Alimentos [TACO], 2011).

Although it has high nutritional value, its consumption is still very low owing to the difficulty in peeling the seeds and the long cooking time (Amarante, Mora, Megguer, \& Ide, 2007; ZortéaGuidolin et al., 2017). In addition, among other reasons, the seasonality of production is responsible for the significant oscillation of prices and its high degree of perishability because of fungal contamination during storage due to high water activity and moisture (50.5\%) of the seeds (Balbinot, Garzel, Weber, \& Ribeiro, 2008). One practical strategy to increase the consumption of pinhão is to produce it minimally processed.

However, even this minimal processing may cause some modifications to the pinhão, making it more susceptible to changes due to the removal of the bark. Among the main modifications observed in minimally processed vegetables are increased respiratory rate; loss of water, nutrients, and firmness; color change; and microbial growth (Santos, Silva, Junqueira, \& Pereira, 2010; Ghidelli \& Pérez-Gago, 2018; Miranda, Marques, Passos, \& Oliveira, 2017).

Edible coatings can be used to preserve the quality and extend the shelf life in a natural and safe way. These coatings are used to inhibit the migration of moisture, reduce the respiratory rate, preserve vitamins (Araújo \& Shirai, 2016), and introduce additives such as antioxidants and antimicrobials, thus improving the intrinsic characteristics of the coated food products (Pérez-Gago, Serra, Alonso, Mateos, \& Rio, 2005). There are no reports in the literature on the application of edible coatings to the pinhão. Chitosan is one of the most studied polymers, mainly because of its antimicrobial action (Sahin, Çarkcioglu, Demirhan, \& Candogan, 2017; Divya, Smitha, \& Jisha, 2018). Additionally, xanthan gum has been used as an edible coating along with other 
compounds that complement the functionality of this gum (Freitas, Cortez-Vega, Pizato, PrenticeHernandez, \& Borges, 2013; Pizato, Cortez-Vega, Hernandez, \& Borges, 2013; Sharma \& Rao, 2015). As xanthan does not possess antimicrobial activity, the use of extracts or essential oils, such as clove essential oil (CEO), that possess this activity could improve and extend its applicability (Trajano, Lima, Souza, \& Travassos, 2009; Medeiros, Gouveia, Bizzo, Vieira, \& Menezzi, 2016).

CEO has a strong antibacterial activity against the main bacteria contaminating food (Trajano et al., 2009) and has antifungal activity due to the presence of eugenol (Rana, Rana, \& Rajak, 2011). As there are no reports of minimal processing of the pinhão, the objective of the present study was to evaluate the effects of different edible coatings with antimicrobial characteristics on the storage stability of minimally processed pinhão.

\section{Material and Methods}

\section{Material}

The pinhão (Araucaria angustifolia) samples were obtained from a producer in the city of Vacaria in the state of Rio Grande do Sul, Brazil. The seeds were collected, packed in bags, and sent to the city of Pelotas, RS. The processing was carried out two days after collection.

\section{Methods}

The solution of chitosan (Polymar, Fortaleza, Brazil) was prepared in acetic acid (Synth, São Paulo, Brazil) (1.5\%) and that of xanthan gum (Shandong Fufeng Fermentation, Linyi, China) in water, both at room temperature with constant stirring until complete dissolution, followed by heating at $60{ }^{\circ} \mathrm{C}$ and subsequent cooling. The emulsifier Tween ${ }^{\circledR} 80$ (Synth, São Paulo, Brazil) and CEO were added to the xanthan gum solution; glycerol was added as a plasticizer to both solutions (Synth, São Paulo,
Brazil). The CEO was extracted according to the method described in the Brazilian Pharmacopoeia (Farmacopeia Brasileira, 2010) by hydrodistillation with the aid of a Clevenger apparatus for $3 \mathrm{~h}$ and stored in an amber flask at a temperature of $-18{ }^{\circ} \mathrm{C}$ until use.

Pinhões (pinhão, plural pinhões) were selected, and those with signs of deterioration or apparent fungal contamination were excluded. They were then washed with water, sanitized in sodium dichloroisocyanurate solution $\left(2 \mathrm{~g} \mathrm{~L}^{-1}\right)$ for $15 \mathrm{~min}$, rinsed with water, and manually peeled with a knife. After peeling, they were again sanitized, rinsed, and centrifuged for $30 \mathrm{sec}$.

The following treatments were evaluated: Treatment A, Control (minimally processed pinhões without coating), Treatment $\mathrm{B}$, minimally processed pinhões coated with chitosan $(1.5 \% \mathrm{w} / \mathrm{v})$ and glycerol $(1.0 \% \mathrm{w} / \mathrm{v})$; Treatment $\mathrm{C}$, minimally processed pinhões coated with xanthan gum $(0.5 \%$ $\mathrm{w} / \mathrm{v})$, Tween ${ }^{\circledR} 80(0.1 \% \mathrm{w} / \mathrm{v}), \mathrm{CEO}(0.2 \% \mathrm{w} / \mathrm{v})$, and glycerol $(1 \% \mathrm{w} / \mathrm{v})$.

The pinhões were completely submerged in the solutions for $1 \mathrm{~min}$ and then drained for 2 to $3 \mathrm{~min}$ to remove excess solution. They were subsequently dried in a stream of air in a refrigerated environment at $17{ }^{\circ} \mathrm{C}$. Finally, the samples were packed in polyethylene terephthalate (PET) packaging with hinged lids and pressure closures, 20 pinhões per package, and stored at $4{ }^{\circ} \mathrm{C}$ and $90 \%$ to $95 \%$ relative humidity for 9 days. The analyses were performed after 1, 3, 6, and 9 days of storage.

\section{Physicochemical analyses}

Mass loss

The loss of mass was obtained by calculating the difference between the initial mass of the minimally processed pinhões and the mass obtained at the end of the storage period. All analyses were performed in triplicate, and the results were expressed as percentages of mass loss. 


\section{Titratable acidity}

Titratable acidity was determined by potentiometric titration of $10 \mathrm{~g}$ of the homogenized sample with $100 \mathrm{~mL}$ of distilled water. The sample was titrated with $0.1 \mathrm{~mol} \mathrm{~L}^{-1}$ of $\mathrm{NaOH}$ solution to a $\mathrm{pH}$ between 8.2 and 8.4. All analyses were performed in triplicate, and the results were expressed as percentages (Instituto Adolfo Lutz [IAL], 2008).

\section{Vitamin $C$}

The sample was ground, and $20 \mathrm{~g}$ was transferred to a $300 \mathrm{~mL}$ Erlenmeyer flask. Then, $50 \mathrm{~mL}$ of water, $10 \mathrm{~mL}$ of $20 \%$ sulfuric acid solution, $1 \mathrm{~mL}$ of $10 \%$ potassium iodide solution, and $1 \mathrm{~mL}$ of $1 \%$ starch solution were added to the sample. The sample was titrated with $0.02 \mathrm{M}$ potassium iodate solution to pink coloration. All analyses were performed in triplicate, and the results were expressed in mg 100 $\mathrm{g}^{-1}$ of the sample (IAL, 2008).

\section{Reducing sugars}

From the ground pinhão, $10 \mathrm{~g}$ of the sample was weighed and transferred to a $100 \mathrm{~mL}$ volumetric flask. The volume was filled with water, and the sample was filtered using a filter paper and a funnel. The filtrate was transferred to a buret. Five milliliters each of the Fehling A and B solutions and $40 \mathrm{~mL}$ of water were added to an Erlenmeyer flask. After boiling, this Fehling's solution was titrated until the solution became colorless. All analyses were performed in triplicate, and the results were expressed as percentages of reducing sugars in glucose (IAL, 2008).

\section{Firmness}

Measurements of the firmness of the pinhão were performed using the TA.XT plus 40855 texturometer (Stable Microsystems, Godalming, UK) using the HDP/BS cutting blade and the HDP/90 base platform.
Compression was used to measure the firmness or force required to cause the rupture of the fruit. The operating parameters used were pre-test velocity of $1.50 \mathrm{~mm} \mathrm{~s}^{-1}$, test velocity of $1.00 \mathrm{~mm} \mathrm{~s}^{-1}$, post-test velocity of $10.00 \mathrm{~mm} \mathrm{~s}^{-1}$, distance of $4 \mathrm{~mm}$, and driving force of $0.147 \mathrm{~N}$. Each experiment was repeated 30 times. The measurement was performed in the equatorial central region of the pinhão with 20 repetitions, and the results were expressed in Newton (N).

\section{Color}

The color was determined using a colorimeter (Minolta CR 400, Minolta, Chiyoda, Japan). In the CIE pattern $\mathrm{L}^{*} \mathrm{a} * \mathrm{~b} *$, the $\mathrm{L} *$ coordinate expresses the degree of luminosity of the measured color $\left(\mathrm{L}^{*}\right.$ $=100=$ white; $\mathrm{L}^{*}=0=$ black); the $\mathrm{a}^{*}$ coordinate expresses the degree of variation between red $(+60)$ and green (-60); and the $b^{*}$ coordinate expresses the degree of variation between blue (-60) and yellow $(+60)$. Eight measurements were performed.

\section{Respiratory rate}

A portable OXYBABY 6.0 Gas Analyzer (Witten-Germany), previously calibrated by atmospheric air sampling, was used for the evaluation of the $\mathrm{CO}_{2}$ and $\mathrm{O}_{2}$ content in the sealed packages. The values were expressed as percentages of $\mathrm{CO}_{2}$ and $\mathrm{O}_{2}$. Four measurements were performed.

\section{Sensorial analysis}

Twenty trained volunteer judges were invited to take the test on two different days. The samples of the minimally processed pinhões were baked for $20 \mathrm{~min}$ in a pressure cooker and sensorially evaluated (taste, aroma) using the triangular test in triplicate (IAL, 2008). On the first day, the judges were offered samples coated with xanthan gum and CEO, along with the control sample (uncoated). On 
the second day, samples coated with chitosan, in addition to the control sample, were offered to the judges. Percent accuracy of the judges was analyzed according to the table of level of significance (5\%) for the triangular test (IAL, 2008).

The study was approved by the Ethics Committee of the School of Medicine of the Federal University of Pelotas (CAAE 12348019.1.0000.5317). All participants provided written informed consent.

\section{Microbiological analyses}

\section{Quantification of thermotolerant coliforms}

The most probable number (MPN) technique was used for the enumeration of thermotolerance. The presumptive analysis of coliforms was carried out in sodium lauryl sulfate broth (LST) (Oxoid: Basinstoke, England) with incubation at $35^{\circ} \mathrm{C}$ for $48 \mathrm{~h}$. The enumeration of thermotolerant coliforms was carried out in Escherichia coli broth (EC) (Acumedia: Lansing-Michigan) with incubation at $45.5^{\circ} \mathrm{C}$ for $48 \mathrm{~h}$. All analyses were performed in triplicate, and the results were expressed as $\mathrm{MPN} \mathrm{g}^{-1}$.

\section{Quantification of aerobic psychrotrophic} microorganisms

The quantification of psychrotrophic microorganisms was performed using the surface sowing method with Plate Count Agar (PCA). Plates were incubated at $7{ }^{\circ} \mathrm{C}$ for 10 days. All analyses were performed in triplicate, and the results were expressed in $\log \mathrm{CFU} \mathrm{g}^{-1}$.

\section{Enumeration of coagulase-positive Staphylococcus}

The surface sowing technique was used to inoculate $0.1 \mathrm{~mL}$ of serially diluted onto Baird Parker agar, followed by incubation at $37{ }^{\circ} \mathrm{C}$ for 24 to $48 \mathrm{~h}$. The colonies were enumerated, and at least five colonies with typical morphology and five atypical colonies were selected to perform a test of free coagulase production. The analyses were performed in triplicate, and the results were expressed in $\log \mathrm{CFU} \mathrm{g}^{-1}$.

\section{Enumeration of fungi}

To count fungi (molds and yeasts), the direct plating method was applied to the surface of Potato Agar Dextrose (Kasvi, Italy). Decimal dilutions were inoculated by scattering and incubated at $25{ }^{\circ} \mathrm{C}$. Counts were performed at three and five days of incubation. The analyses were performed in triplicate, and the results were expressed in log $\mathrm{CFU} \mathrm{g}^{-1}$.

\section{Statistical analysis}

The results were subjected to analysis of variance (ANOVA), and the comparison of means between treatments was performed using Tukey's test with a significance level of 5\% and the STATISTIX 10 program. For the evaluation of the storage time, $95 \%$ confidence intervals were calculated.

\section{Results and Discussion}

Mass loss

When analyzing the mass loss data in relation to time, we observed that there was a significant increase in mass loss values during storage for all of the treatments $(p \leq 0.05)$ (Figure $1 \mathrm{~A})$. However, we did not observe any differences $(p \geq 0.05)$ in the mass loss values for any of the coatings at the end of storage (Supporting Information A). Although there was an increase in mass loss in all of the treatments, the highest percentage observed was only $1.95 \%$ of the initial weight. Thus, the storage of seeds in cold rooms with temperature and relative humidity control may help to control the loss in mass.

Edible coatings can act as barriers to gases and water vapor; however, in this study, the coatings did not behave as barriers to mass loss. To date, the use of coatings has not been analyzed for minimal 
processing of pinhões. The efficiency of coating to reduce the loss of mass seems to depend on the concentration and composition of the coating as well as the characteristics of the vegetable being coated (Araújo \& Shirai, 2016; Freitas et al., 2013). Xing et al. (2015) demonstrated a reduction in the mass loss of Chinese jujube fruits coated with chitosan; however, the mass loss was significantly reduced with the addition of cinnamon oil to the coating. This effect was not observed for the xanthan coating with CEO in our study.

\section{Reducing sugars}
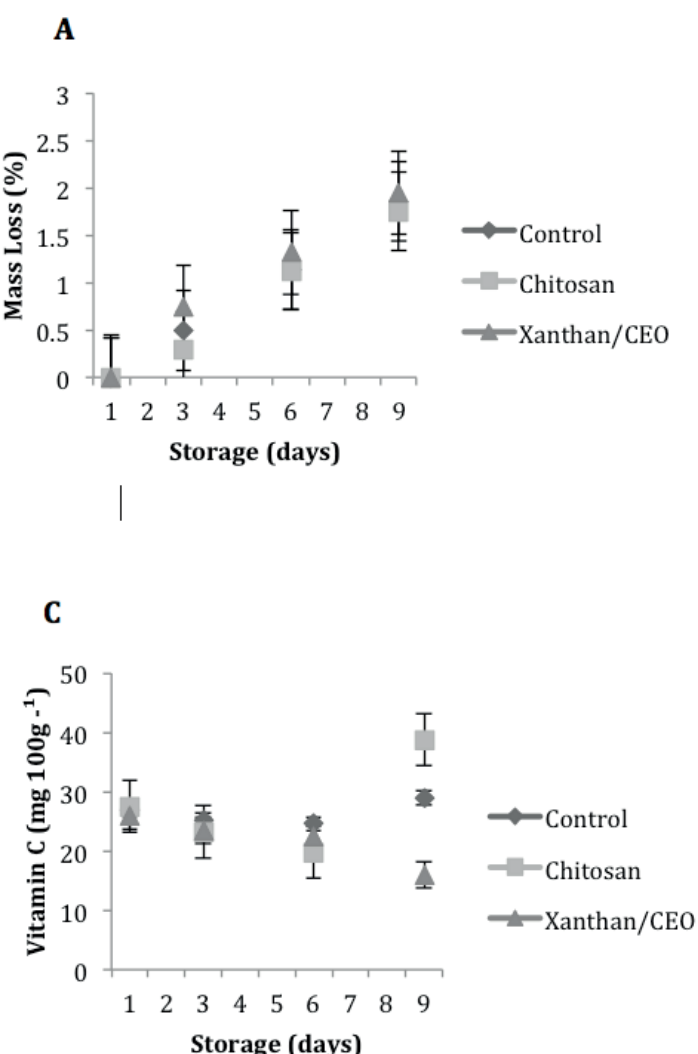

We observed a significant increase $(\mathrm{p} \leq 0.05)$ in the reducing sugar values, regardless of the treatment being evaluated (Figure 1B). At the end of storage, the percentage of reducing sugars $(0.72 \%)$ in the chitosan-coated pinhões was significantly higher than in those coated with xanthan gum/CEO $(0.42 \%)$. However, there was no significant difference $(p \geq 0.05)$ for either coating compared to the control sample $(0.65 \%)$ (Supporting Information B).
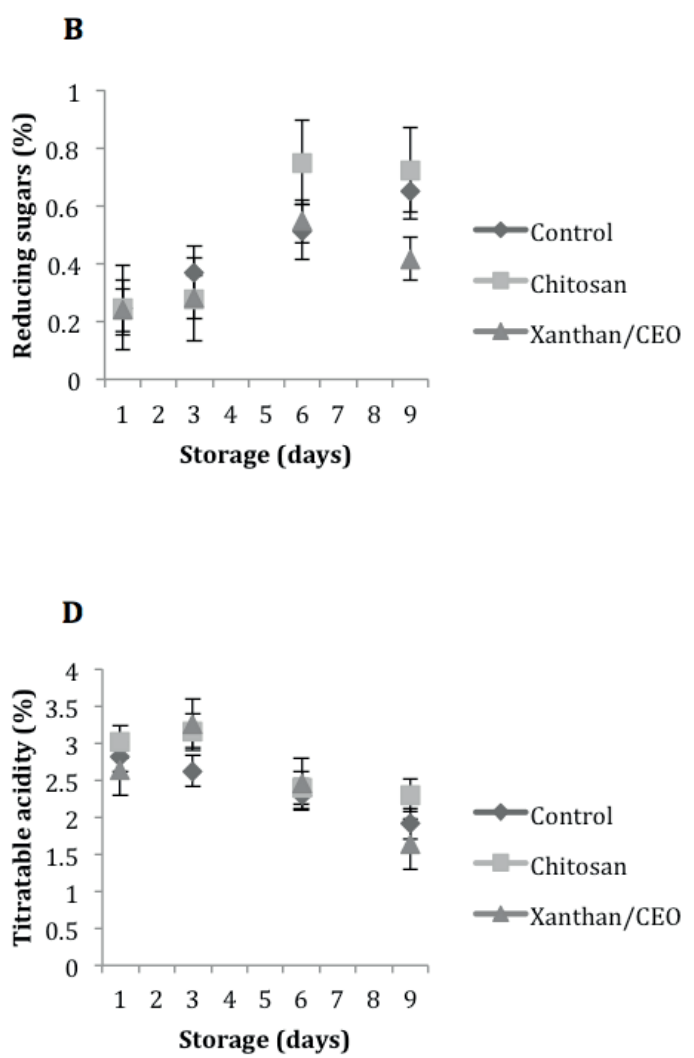

Figure 1. Mass loss (\%) - A, reducing sugars (\%) - B, vitamin C (mg $\left.100 \mathrm{~g}^{-1}\right)-\mathrm{C}$, and titratable acidity (\%) - D of minimally processed pinhões coated with chitosan and xanthan gum/clove essential oil (CEO), stored at $4{ }^{\circ} \mathrm{C}, 90 \%$ to $95 \%$ relative humidity for 9 days. The vertical bars represent $95 \%$ confidence intervals.

The slight increase observed in the reducing sugar values may be due to the conversion of starch to soluble sugars as a function of the maturation process (Toivonen \& Brummell, 2008).
In the study by Jesus, Costa, Godoy and Wasczynskyj (2015), an increase in the reducing sugar levels was observed in fresh pinhões during storage at environmental temperature in different 
packages. In addition, while evaluating the influence of storage on sugar behavior in pinhões, Costa (2014) found an increase in soluble sugars and a decrease in starch content, confirming the inverse relationship between sugar and starch content resulting from the process of maturation.

\section{Vitamin C}

In general, there was an influence of time on vitamin $\mathrm{C}$ content in minimally processed pinhões (Figure 1C). At the end of storage, the vitamin $\mathrm{C}$ content in the control samples remained constant, whereas there was a significant increase $(\mathrm{p} \leq 0.05)$

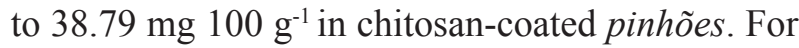
pinhões coated with xanthan gum, we observed a reduction $(\mathrm{p} \leq 0.05)$ in vitamin $\mathrm{C}$ content to $16.04 \mathrm{mg}$ $100 \mathrm{~g}^{-1}$.

Analysis of the results at each time point (Supporting Information C) did not reveal any significant difference between the treatments until the $6^{\text {th }}$ day of analysis. However, on the $9^{\text {th }}$ day of storage, the pinhões coated with chitosan contained higher levels of vitamin $\mathrm{C}(\mathrm{p} \leq 0.05)$ compared to the other treatments.

The pinhão has a vitamin C content of $27.7 \mathrm{mg}$ $100 \mathrm{~g}^{-1}$ (TACO, 2011), and the initial values obtained in the present study are consistent with those in the food composition table.

According to Koblitz (2008), the amount of this vitamin may increase or decrease during ripening based on the release of sugar precursors of vitamin C (ascorbic acid) biosynthesis during the degradation of cell walls. However, the oxidation of vitamin $\mathrm{C}$, which is catalyzed by the action of ascorbic acid oxidase and peroxidases (Chitarra \& Chitarra, 2005), leads to a decrease in vitamin $C$ content.

Oxygen present in the package did not cause oxidation of the vitamin in the control samples. It is possible that the increase in the vitamin $\mathrm{C}$ content in the chitosan-coated pinhões is related to the higher concentration of sugars observed at the end of storage of these pinhões. Treatment with xanthan gum was expected to maintain vitamin $\mathrm{C}$ content because coatings act as oxygen barriers, reducing the oxidation of vitamin C (Araújo \& Shirai, 2016); however, this was not observed in the treatment with xanthan gum and CEO.

\section{Titratable acidity}

We observed a significant decrease in acidity over time, between the first and last days of storage for all three treatments $(p \leq 0.05)$ (Figure 1D).

Despite the variation in the values of acidity for all of the treatments, the pinhões coated with chitosan showed significantly higher percentages of acidity $(p \leq 0.05)$ throughout storage than the other treatments (Supporting Information D). On the ninth day of analysis, seeds coated with chitosan showed $2.30 \%$ acidity, whereas those coated with xanthan/CEO showed $1.64 \%$ acidity. These results can be attributed to the use of acetic acid for the dissolution of chitosan.

The decrease in acidity is due to the consumption of organic acids during respiration or their conversion to sugars. Thus, acidity tends to decrease with the advancement of maturation; however, a small increase may also occur (Chitarra \& Chitarra, 2005). The increase in acidity may be related to the degradation of the cell wall as a function of metabolism (Siqueira, 2012).

The reduction in acidity observed in this study for all treatments may be related to the higher sugar content observed in all treatments.

Contrary to what was found in the present study, Oliveira (2008) observed a slight tendency of increase in the acidity of fresh pinhões stored under refrigeration and freezing, but for a longer period of 2 to 9 months. 


\section{Respiratory activity}

Regardless of the treatment, Araucaria seeds showed an increase in oxygen levels $\left(\mathrm{O}_{2}\right)$ (Figure $2 \mathrm{~A})$ and a decrease in carbon dioxide $\left(\mathrm{CO}_{2}\right)$ levels (Figure 2B) over time, with significant differences between the first day of storage and the rest $(p \leq 0.05)$. There were no significant differences in the gas profiles with respect to the different treatments $(p \geq 0.05)$ (Supporting Information $E$ and $F$ ).
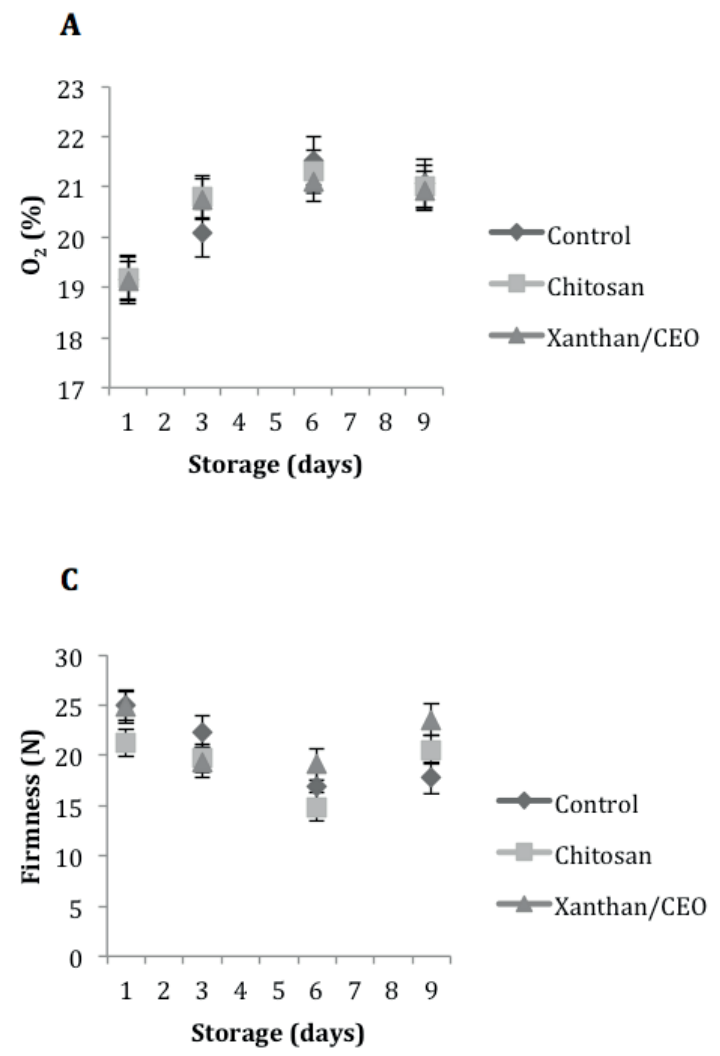

Respiration can be defined as the oxidative degradation of complex substances (starch, sugars, lipids, proteins, acids) into simpler molecules $\left(\mathrm{CO}_{2}\right.$ and $\mathrm{H}_{2} \mathrm{O}$ ), leading to the generation of energy and molecules used in synthesis reactions (Koblitz, 2008).

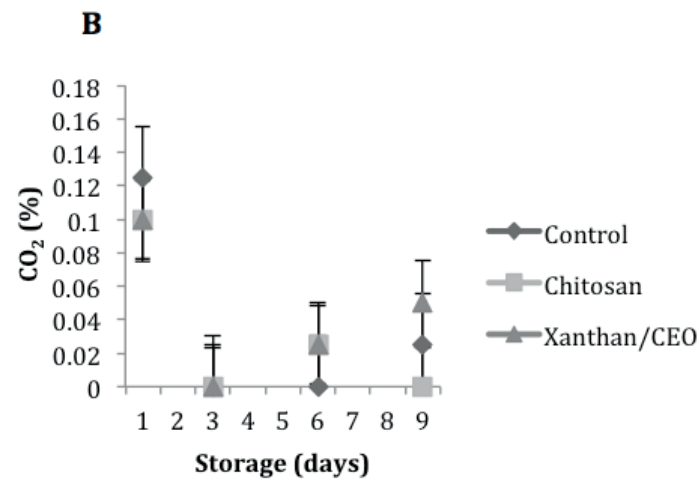

Figure 2. Oxygen (\%) - A, carbon dioxide (\%) - B in the storage atmosphere and firmness $(\mathrm{N})$ - C of minimally processed pinhões coated with chitosan and xanthan gum/clove essential oil (CEO), stored at $4{ }^{\circ} \mathrm{C}, 90 \%$ to $95 \%$ relative humidity for 9 days. The vertical bars represent $95 \%$ confidence intervals.

Our results demonstrate that minimal processing, regardless of the treatment, did not increase the respiratory rate. The increase in sugar concentration (Figure 1B) may be related to the maturation process, the enzymatic hydrolysis of the starch, and the conversion of the acids to sugars.
Amarante et al. (2007) demonstrated the effect of temperature on the respiratory rate of pinhões. Low respiratory rates were observed when seeds were stored at temperatures between $2{ }^{\circ} \mathrm{C}$ and 10 ${ }^{\circ} \mathrm{C}$. Seeds tend to decrease their metabolic activity at lower temperatures due to decreased respiration (Costa, 2014). 


\section{Firmness}

When the firmness of the minimally processed pinhão was evaluated, we observed that there was a significant decrease $(\mathrm{p} \leq 0.05)$ in the cutting force for both coatings during storage until the sixth day, which plateaued for the control sample, but increased significantly for both coatings ( $\mathrm{p} \leq 0.05$ ) (Figure $2 \mathrm{C}$ ). In general, no significant differences were observed between treatments (Supporting Information G).

Jesus et al. (2015) had also observed a decrease in firmness of pinhões throughout the storage period. Minimally processed vegetables tend to lose water from the tissues, leading to loss of mass and changes in texture and consequently, deterioration of the quality of the product (Toivonen \& Brummell, 2008). The activity of pectinase enzymes also contributes to a reduction in plant firmness (Koblitz, 2008). In contrast, an increase in firmness may be related to the loss of moisture leading to the formation of a crust on the surface of the vegetable
(Koblitz, 2008) as well as the presence of a coating that offers mechanical protection (Cerqueira, Teixeira, \& Vicente, 2016).

The values obtained in the present study are similar to those reported by Costa (2014).

\section{Color}

Different behaviors were observed among the evaluated groups with respect to the $\mathrm{L}^{*}$ coordinate, which represents the degree of luminosity. There was no significant variation in the results over time $(\mathrm{p} \geq 0.05)$ for the control samples. The brightness values of the pinhões coated with chitosan varied considerably during storage. However, there was a significant increase in brightness $(\mathrm{p} \leq 0.05)$ (Figure $3 \mathrm{~A})$ of pinhões coated with xanthan gum/CEO. At the end of the storage period, there was no difference in the brightness of the control and xanthan-coated pinhões $(\mathrm{p} \geq 0.05)$ (Supporting Information $\mathrm{H}$ ).
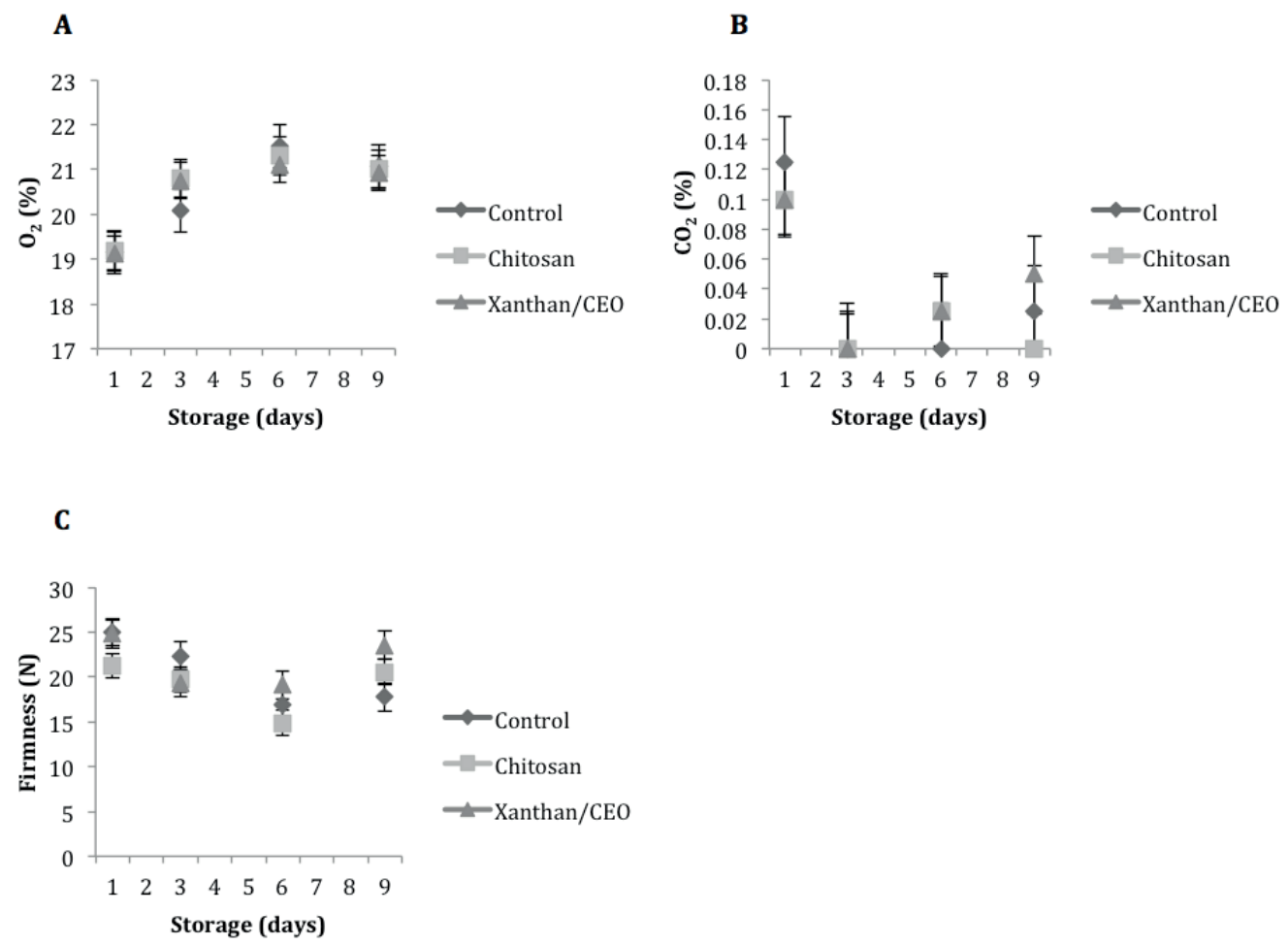

Figure 3. Color $\left(\mathrm{L}^{*}\right)$ - $\mathrm{A}$, color $\left(\mathrm{a}^{*}\right)$ - $\mathrm{B}$ and color $\left(\mathrm{b}^{*}\right)$ - $\mathrm{C}$ of minimally processed pinhões coated with chitosan and xanthan gum/clove essential oil (CEO), stored at $4{ }^{\circ} \mathrm{C}, 90 \%$ to $95 \%$ relative humidity for 9 days. The vertical bars represent $95 \%$ confidence intervals. 
All of the pinhão samples were white, suggesting the absence of activity of the poliphenoloxidase enzyme. Moreover, the higher degradation of vitamin $\mathrm{C}$ (and consequent production of the pigment, melanoidin), observed in the treatment of pinhões with xanthan gum/CEO, seems to have no effect on the values of luminosity (Figure 3A).

With regard to the values of a*, which represents the degree of variation between green and red colors, no significant difference was observed over the storage period $(\mathrm{p} \geq 0.05)$ (Figure $3 \mathrm{~B}$ ) or between treatments (Supporting Information I). These values indicated that the samples tended to red, reaching values of $1.30,2.32$, and 1.11 for the control, chitosan, and xanthan/OEC treatments, respectively, at the end of the storage period.

When evaluating the $b^{*}$ coordinate, which reflects the variation between yellow and blue, we found that all seeds tended to yellow, and neither the duration of storage nor the treatments influenced the results at the end of storage ( $\mathrm{p} \geq 0.05$ ) (Figure $3 \mathrm{C}$, Supporting Information J).

Costa (2014) had reported initial values of 81.50, 4.30, and 16.65 for the coordinates $\mathrm{L}^{*}, \mathrm{a}^{*}$, and $b^{*}$, respectively. With the exception of the $a^{*}$ coordinate, these results are in agreement with our results in the present study.

\section{Sensory analysis}

The triangular test was used to detect any sensorial differences in the taste and aroma of the pinhões due to the presence of the coatings. Among the 60 judgments, there were 22 hits for pinhões coated with xanthan gum and CEO and 23 hits for the seeds coated with chitosan.

According to the table of significance level for the triangular test (IAL, 2008), the minimum number of hits required to detect differences at the $5 \%$ level of significance for a total of 60 trials is 27 hits. Thus, as we obtained $<27$ hits for all three treatments, we concluded that there was no significant difference $(p \geq 0.05)$ in the taste and aroma of the coated pinhões compared to the control samples. These results indicate that these two coatings could be used to improve storage stability of minimally processed pinhões. Perdones, Sánchez-González, Chiralt, \& Vargas (2012) had detected the taste of the coatings of chitosan and lemon essential oil on strawberries. However, we did not detect the taste of the coatings in our study, possibly because of the cooking of the pinhões in water.

\section{Microbiological analyses}

Quantification of thermotolerant coliforms and coagulase-positive Staphylococcus

Thermotolerant coliforms as well as coagulasepositive Staphylococcus were not detected in the samples. This demonstrates that the sanitization of surfaces and utensils with a chlorine-based sanitizer and the Good Manufacturing Practices associated with the coatings were effective in avoiding such microorganisms.

\section{Quantification of aerobic psychrotrophic microorganisms}

No growth of psychrotrophic microorganisms was observed until the third day of analysis, regardless of the treatment. However, there was an increase in the growth of psychrotrophic microorganisms in the minimally processed pinhões $(\mathrm{p} \leq 0.05)$ (Figure $4 \mathrm{~A}$ ). The pinhões of the control sample and those coated with xanthan and CEO showed significantly higher growth on the ninth day of analysis $(\mathrm{p} \leq 0.05)$ than the chitosan-coated pinhões (Supporting Information $\mathrm{K})$. The CEO added in the xanthan gum coating was not effective in reducing the growth of these microorganisms, possibly due to the evaporation of the essential oil, as described by $\mathrm{Vu}$, Hollingsworth, Salmieri and Lacroix (2011). 
A

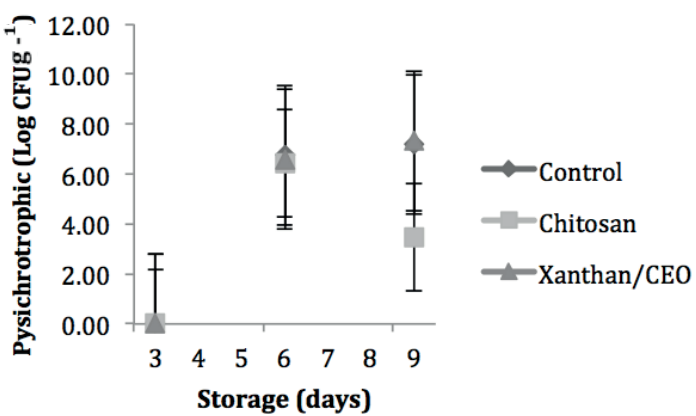

B

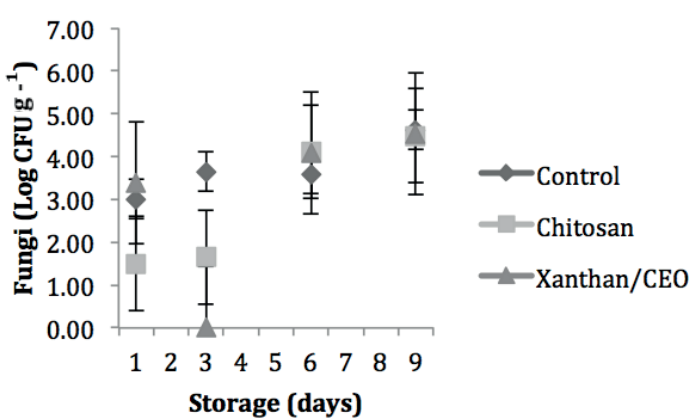

Figure 4. Counts of aerobic psychrotrophic microorganisms $\left(\log \mathrm{CFU} \mathrm{g}{ }^{-1}\right)$ - $\mathrm{A}$ and fungal $\left(\log \mathrm{CFU} \mathrm{g}{ }^{-1}\right)$ - B in minimally processed pinhões coated with chitosan and xanthan gum/clove essential oil (CEO), stored at $4{ }^{\circ} \mathrm{C}, 90 \%$ at $95 \%$ relative humidity for 9 days. The vertical bars represent $95 \%$ confidence intervals.

The antimicrobial activity of chitosan is not yet clear. However, electrostatic interactions, which cause a change in the permeability and the loss of electrolytes and intracellular protein components of bacteria, may help to understand the antimicrobial effects of chitosan (Devlieghere, Vermeulen, \& Debevere, 2004). Over time, there is a decrease in the antimicrobial activity of chitosan due to the depletion of amine groups bound to bacterial cells, which become unavailable to bind to other cell surfaces (Sudarshan, Hoover, \& Knorr, 1992).

Studies on the use of chitosan in minimally processed vegetables have shown protection against psychrotrophic microorganisms in vegetables (Botrel, Soares, Geraldini, Pereira, \& Fontes, 2007; Moreira, Roura, \& Ponce, 2011). However, Freitas et al. (2013) observed that xanthan gum base coating stimulated the growth of psychrotrophic microorganisms in minimally processed apples.

The presence of Pseudomonas sp., the main psychrotrophic microorganism found in foods preserved under refrigeration, is responsible for reducing the shelf life of these foods due to the degradation of proteins and lipids by proteases and lipases (Garg, Churey, \& Splittstoesser, 1990). There is still no specific legislation regarding the counting of psychrotrophic microorganisms for minimally processed vegetables.

\section{Enumeration of fungi}

There was no significant increase in fungal counts during storage of the minimally processed pinhões $(\mathrm{p} \geq 0.05)$ (Figure $4 \mathrm{~B})$. At the end of the experiment, all treatments showed similar fungal counts ( $\mathrm{p} \geq 0.05$ ) (Supporting Information $\mathrm{L}$ ).

Our results were consistent with those reported by Santos, Boas, Prado, and Pinheiro (2005) for minimally processed pineapples. In the study by Pinheiro, Figueiredo, Figueiredo, Maia, \& Souza (2005), higher values between 2 and $7 \log$ CFU $\mathrm{g}^{-1}$ were obtained for minimally processed fruits, indicating that the counts depend on the raw material. In addition, Norte (2015) found no decrease in fungal growth with the use of xanthan with CEO to coat processed peppers and attributed this to the high volatility of the essential oil and high oxidation capacity of the oil.

There is still no specific legislation on fungal counts for minimally processed vegetables.

Penicillium sp. are important storage fungi that affect the pinhões (Hennipman, Santos, Vieira, \& Auer, 2017) and may be indicators of the deterioration of seeds and grains (Cardoso et al., 2011). 


\section{Conclusion}

In this study, we performed minimal processing of pinhões, which could be facilitated by the use of techniques that aid dehulling. In general, similar values were observed for increase in mass loss, reducing sugars, and oxygen concentrations of the pinhões after all treatments. In addition, we observed a reduction in acidity and carbon dioxide concentrations as well as the maintenance of color parameters and the absence of growth of thermotolerant coliforms and coagulase-positive Staphylococcus. However, differences were observed in vitamin $\mathrm{C}$ content and firmness of the pinhões. Minimal processing did not increase the respiratory rates of the pinhões; however, it did not stop the process of seed maturation. Of the coatings evaluated, chitosan coating was associated with a higher content of vitamin $\mathrm{C}$ as well as a lower number of psychrotrophic microorganisms. The coatings did not influence the taste and aroma of minimally processed pinhões. Thus, this study highlights the use of edible coating as a minimal processing technique to increase the shelf life of the Pinhão and provide greater microbiological safety for this seed, which should promote the consumption of pinhões.

\section{Acknowledgements}

This study was partly funded by the Coordenação de Aperfeiçoamento de Pessoal de Nível Superior Brazil (CAPES) - Finance Code 001.

\section{References}

Amarante, C. V. T., Mora, C. S., Megguer, C. A., \& Ide, G. M. (2007). Conservação pós-colheita de pinhões [sementes de Araucaria angustifolia (Bertoloni) Otto Kuntze] armazenados em diferentes temperaturas. Revista Ciência Rural, 37(2), 346-351. doi: 10.1590/ S0103-84782007000200008

Araújo, V. R., \& Shirai, M. A. (2016). Aplicação de revestimento comestível de quitosana em brócolis minimamente processado. Boletim do Centro de Pesquisas de Processamento de Alimentos, 34(2), 1-10. doi: 10.5380/cep.v34i2.53188

Balbinot, R., Garzel, J. C. L, Weber, K. S., \& Ribeiro, A. B. (2008). Tendências de consumo e preço de comercialização do pinhão (semente da Araucaria angustifolia (Bert.) O. Ktze.), no estado do Paraná. Revista Ambiência, 4(3), 463-472.

Botrel, D. A., Soares, N. F. F., Geraldini, R. M., Pereira, R. M., \& Fontes, E. A. F. (2007). Qualidade de alho (Allium sativum) minimamente processado envolvido com revestimento comestível antimicrobiano. Ciências e Tecnologia de Alimentos, 27(1), 32-38. doi: 10.1590/S0101-20612007000100006

Farmacopeia Brasileira (2010). Farmacologia brasileira. Brasília, DF: Agência Nacional de Vigilância Sanitária.

Cardoso, F. C., Fo, Calvet, R. M., Pereyra, C. M., Rosa, C. A. R., Torres, A. M., \& Muratori, M. C. S. (2011). Ocorrência de Aspergillus spp., Penicillium spp. e aflatoxinas em amostras de farinha de milho utilizadas no consumo humano, Piauí, Brasil. Arquivos do Instituto Biológico, 78(3), 443-447.

Cerqueira, M. A., Teixeira, J. A., \& Vicente, A. A. (2016). Edible food packaging: materials and processing technologies. Florida: CRC Press.

Chitarra, M. I. F., \& Chitarra, A. B. (2005). Pós-colheita de frutos e hortaliças: fisiologia e manuseio. Lavras: ESAL/FAEPE.

Companhia Nacional de Abastecimento (2014). Pinhão (semente). Recuperado de http://www.conab.gov.br/ OlalaCMS/uploads/arquivos/14_09_09_12_36_06 pinhaos ementesetembro_2014.pdf

Costa, F. J. O. G. (2014). Avaliação, caracterização de pinhão (sementes de Araucaria angustifolia) nativas do estado do Paraná e seu uso em um produto alimentício. Tese de doutorado, Universidade Federal do Paraná, PR, Brasil.

Devlieghere, F., Vermeulen, A., \& Debevere, J. (2004). Chitosan: antimicrobial activity, interactions with food components and applicability as a coating on fruit and vegetables. Food Microbiology, 21(6), 703714. doi: 10.1016/j.fm.2004.02.008

Divya, K., Smitha, V., \& Jisha, M. S. (2018). Antifungal, antioxidant and cytotoxic activities of chitosan nanoparticles and its use as an edible coating on vegetables. International Journal of Biological Macromolecules, 114, 572-577. doi: 10.1016/j. ijbiomac.2018.03.130 
Freitas, I. R., Cortez-Vega, W. R., Pizato, S., PrenticeHernandez, C., \& Borges, C. D. (2013). Xanthan gum as a carrier of preservative agents and calcium chloride applied on fresh-cut apple. Journal of Food Safety, 33(3), 229-238. doi: 10.1111/jfs.12044

Garg, N., Churey, J. J., \& Splittstoesser, D. F. (1990). Effect of processing conditions on the microflora of fresh-cut vegetables. Journal of Food Protection, 53(8), 701-703. doi: 10.4315/0362-028X-53.8.701

Ghidelli, C., \& Pérez-Gago, M. B. (2018). Recent advances in modified atmosphere packaging and edible coatings to maintain quality of freshcut fruits and vegetables. Critical Reviews in Food Science and Nutrition, 58(4), 662-679. doi: 10.1080/10408398.2016.1211087

Hennipman, H. S., Santos, A. F., Vieira, E. S. N., \& Auer, C. G. (2017). Qualidade sanitária e fisiológica de sementes de araucária durante armazenamento. Ciência Florestal, 27(2), 643-654. doi: 10.5902/198050 9827749

Instituto Adolfo Lutz (2008). Métodos físico-químicos para análise de alimentos. São Paulo, SP: Instituto Adolfo Lutz.

Jesus, A. M. F., Costa, J. O. G., Godoy, R. C. B., \& Wasczynskyj, N. (2015). Alterações físico-químicas ocorridas em pinhões armazenados a granel. Anais do Encontro Regional Sul de Ciência e Tecnologia de Alimentos, Curitiba, PR, Brasil, 13.

Koblitz, M. G. B. (2008). Bioquímica de alimentos-teoria e aplicações práticas. Rio de Janeiro: Guanabara Koogan.

Medeiros, F. C. M., Gouveia, F. M., Bizzo, H. R., Vieira, R. F., \& Menezzi, C. H. S. D. (2016). Fungicidal activity of essential oils from Brazilian Cerrado species against wood decay fungi. International Biodeterioration \& Biodegradation, 114, 87-93. doi: 10.1016/j.ibiod.2016.06.003

Miranda, A. L. S., Marques, D. R. P., Passos, L. P., \& Oliveira, I. R. N. (2017). Efeito do tipo de embalagem e do tempo de armazenamento nas qualidades físicoquímicas de cenoura minimamente processada. The Journal of Engineering and Exact Sciences, 3(6), 807-812. doi: 10.18540/jcecvl3iss6pp0807-0812

Moreira, M. D. R., Roura, S. I., \& Ponce, A. (2011). Effectiveness of chitosan edible coatings to improve microbiological and sensory quality of fresh cut broccoli. LWT - Food Science and Technology, 44(10), 2335-2341. doi: 10.1016/j.lwt.2011.04.009
Norte, M. I. J. (2015). Revestimento comestivel antifúngico aplicado em pimentão 'DAHRA'. Dissertação de mestrado, Instituto Federal de Educação, Ciência e Tecnologia do Ceará, Limoeiro do Norte, Ceará, Brasil.

Oliveira, F. C. (2008). Estudos tecnológicos e de engenharia para o armazenamento e processamento do pinhão. Tese de doutorado, Universidade Federal do Rio Grande do Sul, Porto Alegre, RS, Brasil.

Perdones, A., Sánchez-González, L., Chiralt, A., \& Vargas, M. (2012). Effect of chitosan-lemon essential oil coatings on storage-keeping quality of strawberry. Postharvest Biology and Technology, 70, 32-41. doi: 10.1016/j.postharvbio.2012.04.002

Pérez-Gago, M. B., Serra, M., Alonso, M., Mateos, M., \& Rio, M. A. D. (2005). Effect of whey proteinand hydroxypropyl methylcellulose-based edible composite coatings on color change of fresh-cut apples. Postharvest Biology and Technology, 36(1), 77-85. doi: 10.1016/j.postharvbio.2004.10.009

Pinheiro, M. S., Figueiredo, E. A. T., Figueiredo, R. W., Maia, G. A., \& Souza, P. H. M. (2005). Avaliação da qualidade microbiológica de frutos minimamente processados comercializados em supermercados de Fortaleza. Revista Brasileira Fruticultura, 27(1), 153-156. doi: 10.1590/S0100-29452005000100040

Pizato, S., Cortez-Vega, W. R., Hernandez, C. P., \& Borges, C. D. (2013). Efeito da aplicação de diferentes revestimentos comestíveis na conservação de maçãs 'Royal Gala' minimamente processadas. Revista Semina: Ciências Agrárias, 34(1), 253-264. doi: 10.5433/1679-0359.2013v34n1p253

Rana, I. S., Rana, A. S., \& Rajak, R. C. 2011. Evaluation of antifungal activity in essential oil of the Syzygium aromaticum (L.) by extraction, purification and analysis of its main component eugenol. Brazilian Journal of Microbiology, 42(4), 1269-1277. doi: $10.1590 / \mathrm{S} 1517-83822011000400004$

Sahin, A., Çarkcioglu, E., Demirhan, B., \& Candogan, K. (2017). Chitosan edible coating and oxygen scavenger effects on modified atmosphere packaged sliced sucuk. Journal of Food Processing and Preservation, 41(6), 1-8. doi: 10.1111/jfpp.13213

Santos, J. C. B., Boas, E. V. B. V., Prado, M. E. T., \& Pinheiro, A. C. M. (2005). Avaliação da qualidade do abacaxi "pérola" minimamente processado armazenado sob atmosfera modificada. Ciência e Agrotecnologia, 29(2), 353-361. doi: 10.1590/ S1413-70542005000200012 
Santos, T. B. A., Silva, N., Junqueira, V. C. A., \& Pereira, J. L. (2010). Microrganismos indicadores em frutas e hortaliças minimamente processadas. Brazilian Journal of Food Tecnology, 13(2), 141-146. doi: 10.4260/BJFT2010130200019

Sharma, S., \& Rao, T. V. R. (2015). Xanthan gum based edible coating enriched with cinnamic acid prevents browning and extends the shelf-life of fresh-cut pears. LWT - Food Science and Technology, 62(1), 791-800. doi: 10.1016/j.1wt.2014.11.050

Siqueira, A. P. O. (2012). Uso de coberturas comestiveis na conservação pós-colheita de goiaba e maracujáazedo. Dissertação de mestrado, Universidade Estadual do Norte Fluminense, Rio de Janeiro, RJ, Brasil.

Sudarshan, N. R., Hoover, D. G., \& Knorr, D. (1992). Antibacterial action of chitosan. Food Biotechnology, 6(3), 257-272. doi: 10.1080/08905439209549838

TACO (2011). Tabela Brasileira de Composição de Alimentos. Campinas: NEPA-UNICAMP. Recuperado de http://www.cfn.org.br/wpcontent/ uploads/2017/03/taco_4_edicao_ampliada_e_ revisada.pdf

Toivonen, P. M. A., \& Brummell, D. A. (2008). Biochemical bases of appearance and texture changes in fresh-cut fruit and vegetables. Postharvest Biology and Technology, 48(1), 1-14. doi: 10.1016/j. postharvbio.2007.09.004
Trajano, V. N., Lima, E. D., Souza, E. L., \& Travassos, A. E. R. (2009). Propriedade antibacteriana de óleos essenciais de especiarias sobre bactérias contaminantes de alimentos. Ciência e Tecnologia de Alimentos, 29(3), 542-545. doi: 10.1590/S010120612009000300014

Vu, K. D., Hollingsworth, R. G., Salmieri, S., \& Lacroix, M. (2011). Development of edible bioactive coating based on modified chitosan for increasing the shelf life of strawberries. Food Research International, 44(1), 198-203. doi: 10.1016/j.foodres.2010.10.037

Xing, Y., Lin, H., Cao, D., Xu, Q., Han, W., Wang, R.,... Li, X. (2015). Effect of chitosan coating with cinnamon oil on the quality and physiological attributes of China jujube Fruits. BioMed Research International, 2015, 1-10. doi: 10.1155/2015/835151

Zortéa-Guidolin, M. E. B., Demiate, 1. M., Godoy, R. C. B., Scheer, A. P., Grewell, D., \& Jane, J. L. (2017). Structural and functional characterization of starches from Brazilian pinion (Araucaria angustifolia). Food Hydrocolloids, 63, 19- 26. doi: 10.1016/j. foodhyd.2016.08.022 